\title{
DINAMIKA PEMIKIRAN KEISLAMAN IKHWAN MANTAN PREMAN DI KELURAHAN SEMANGGI SURAKARTA
}

\author{
Warsito \\ Sekolah Tinggi Islam al-Mukmin Surakarta \\ ayasyabid@gmail.com
}

\begin{abstract}
The term hoodlum is associated with vicious activities while ikhwan is associated with religious activities. Phenomenon appeared when religious activities conducted by ikhwan eks hoodlum. This phenomenon appeared in Mojo village, Semanggi, Pasar Kliwon, Surakarta. This village had bad history. Any kind of bad activities were found in this village but the social life changed since 1999. The villagers agreed to close three prostitution locations in this village. Then, Islamic invitation came to hoodlums, step by step, their lives changed to be better. Researcher divides their lives into three periods. First, they were being good Muslims; second, they joined to lascar activities, third, the period after the general leader of lascars died. Based on this reality, researcher focused this study on the Islamic understanding of ikhwan eks hoodlum, some factors that shaped their understandings, and the impacts of their Islamic understandings. This study used qualitative method with interactiosme symbolic approach. This theory said that human being activities based on their symbol understanding. This understanding was formed by social interacts. To support this method, the writer used social learned and Islamic invitation (dakwah) that shaped their Muslim personalities. Among three periods, lascar period took more proportions. They joined sweeping violent
\end{abstract}


activities and they against many hoodlums physically. These activities made many hoodlums areas be Islamic village. Apart from that, second period have produced extreme thought of some ikhwan.

Keywords: Islam, Ikhwan, Hoodlum, Lascar

\begin{abstract}
Abstrak
Kata preman identik dengan orang yang melakukan tindakan kemungkaran sedangkan kata ikhwan identik dengan orang yang melakukan kegiatan keagamaan. Fenomena muncul ketika kegiatan keagamaan dilakukan oleh seorang ikhwan mantan preman. Fenomena ini muncul di kampong Mojo Kelurahan Semanggi. Kampong Mojo memilikei riwayat kehidupan preman yang parah. Semua bentuke kemaksiatan ada di kampong ini. Kehidupan social mulai berubah mulai tahun 1999, warga kampong sepakat menutup tiga tempat prostitusi di kampong itu. Setelah itu, dakwah mulai menyentuh para preman. Sedikit demi sedikit kehidupan mereka mulai berubah. Peneliti membagi tiga masa perubahan ikhwan mantan preman. Pertama, masa taubat dan dakwah ust Andi, kedua, masa menjadi lascar, ketiga masa pasca meninggalnya pimpinan lascar. Untuk itu, penilitian ini menitikan beratkan pada pemahaman keislaman ikhwan mantan preman, faktor-faktor yang mempengarubi pemahaman mereka dan dampak pemahaman mereka pada setiap masa. Penelitian ini menggunakan metode penelitian kualitative, dengan pendekatan interaksiosme simbolik. Pendekatan ini menjelaskan tentang tindakan seseorang berdasarkan pemahaman mereka pada symbol yang berada di sosial. Pemahaman akan pemaknaan symbol ini tumbub karena adanya interaksi sosial. Untuk mendukung penelitian, peneliti menggunakan teori belajar sosial dan psikologi dakwah dalam pembentukan kepribadian muslim. Diantara tiga periode yang dialami ikhwan, masa menjadi lascar adalah masa yang paling banyak menjadi sorotan. Mereka mengikuti gerakan nabi mungkar dan bergesekan serta adu fisik dengan preman. Banyak kantong-kantong preman yang takluk kemudian menjadi kampong yang islami. Selain membuat perubahan besar dalam kehidupan masyarakat Solo, periode kedua adalah periode munculnya pemikiran-pemikiran yang ekstrim pada sebagian ikhwan.
\end{abstract}

Kata kunci: Islam, Ikhwan, Preman, Laskar 


\section{A. Pendahuluan}

Kata ikhwan merupakan jama dari kata akhu yang memiliki makna saudara. ${ }^{1}$ Tetapi dalam perkembangan pemaknaan dalam bahasa komunikasi di Indonesia, kata ikhwan sering diartikan sebagai laki-laki dewasa aktivis Islam meskipun berjumlah satu. Mereka aktif dalam kegiatan keagamaan di masyarakat atau masjid. Kata preman merupakan sebutan yang merujuk pada laki-laki yang melakukan tindakan kejahatan seperti penodong, perampok, pemeras dan lain sebagainya. ${ }^{2}$ Kehidupan mereka cenderung merugikan masyarakatumum. Sehingga ikhwan mantan preman merupakan laki-laki dewasa yang sebelumnya melakukan tindakantindakan kejahatan kemudian bertaubat dan beralih menjadi pribadi yang mengerjakan ajaran agama Islam serta aktif dalam kegiatan kebaikan yang lain.

Dalam kehidupan di Kota Solo, banyak gesakan fisik antara preman dengan ikhwan mantan preman, baik itu gesekan dalam skala kecil seperti pembubaran perjudian, mabuk-mabukan, dan sweeping kemaksiatan, ataupun gesekan dalam skala besar yang mendorong kepolisian mengerahkan personelnya untuk berjaga. Salah satu gesekan skala besar adalah peristiwa penyerangan umat Islam dari berbagai daerah ke Desa Gandekan, Kampung Sewu, Surakarta tahun 2012. Kejadian yang berawal dari penyiksaan dua orang aktivis masjid yang bernama Agus Pamuji dan Sandinino oleh preman pimpinan Iwan Walet. Ketika dua ikhwan pulang dari ta'ziyah melewati kampong Kadirejo, ada sekelompok preman yang mengetahui mereka sebagai anggota laskar lalu menjegat. Karena kalah jumlah, mereka dianiaya. Kejadian membuat ratusan umat Islam dari berbagai daerah berkumpul dan menyerang Desa Gandekan. ${ }^{3}$ 1997, hal 12

${ }^{1}$ Ahmad Warson Munawir, Al-Munawir, Surabaya: Pustaka Progressif,

${ }^{2}$ (http://kbbi.web.id/preman-2. Sabtu 13 Agustus 2016)

${ }^{3}$ wawancara pertama dengan Ust Agus Junaidi (korlap lascar ketika penyerangan), 10 Oktober 2016 
Sejak tahun 2000, terjadi perubahan mental sosial di Kota Solo, banyak daerah preman yang mulai berubah menjadi daerah yang kondusif dan islami. Para preman bertaubat dan menekuni kegiatan keagamaan.Salah satu daerah yang banyak terdapat ik.hwan mantan preman adalah Mojo Semanggi. Daerah Mojo Semanggi, dulu merupakan daerah hitam. Menurut Bapak Fajar (aktivis dakwah dan takmir masjid setempat), satu gang yang jaraknya tidak lebih dari lima ratus meter saja minimal terdapat dua kumpulan orang-orang yang mabuk-mabukan. Sedangkan menurut Ustadz Burhan, di wilayah Mojo terdapat semua bentuk kemaksiatan, mabuk-mabukan, perzinahan, pencurian, dan perkelahian. Bahkan beliau menuturkan bahwa ia sempat mau dipukuli karena dakwahnya. Karena banyaknya kemasiatan di daerah itu, penduduk setempat menamai jalan masuk ke kampung mereka dengan nama CoMal. (Singkatan Copet Maling). ${ }^{4}$

Perjalanan pemahaman ikhwan mantan preman mengalami tiga tahapan. Tahapan pertama adalah kesadaran untuk bertaubat yang dipelopori oleh dakwah Ustadz Andi. Tahapan kedua adalah tahapan ikhwan masuk dunia laskar yang dipelopori dakwah Ustadz Sigit Qardawi. Sedang tahapan ketiga adalah kehidupan ikhwan mantan preman paska meninggalnya ustad Sigit Qardawi. Setiap tahapan pada proses perubahan memiliki keunikan yang berbeda satu sama yang lain. Peneliti membahas faktor-faktor yang mempengaruhi perubahan, bentuk pengamalan ajaran Islam dan dampak dari pengamalan tersebut.

Penelitian ini akan menggunakan pendekatan interaksi simbolik. Menurut Sutopo, Interaksi Simbolik sejalan dengan pendekatan fenomenologis, dasar pandangan atas interaksi simbolik adalah asumsi bahwa pengalaman manusia diperoleh lewat interpretasi. Cara pandang manusia terhadap suatu istilah atau benda berbeda antara satu orang dengan orang yang lain. Perbedaan pandangan ini karena adanya perbedaan interpretasi terhadap

\footnotetext{
${ }^{4}$ Wawancara ke-dua dengan Ust Fajar As Shidiq (Ustad mantan preman), 11 November 2016
} 
istilah atau benda tersebut. Salah satu faktor yang mempengaruhi interpretasi seseorang adalah background masa lalu. ${ }^{5}$

Menurut teori ini, semua tindakan manusia berdasarkan pemahaman-pemahaman mereka terhadap simbol-simbol yang ada di masyarakat. Menurut Blunner dalam M.Djamal pendekatan interaksionisme simbolik menggunakan asumsi-asumsi sebagai berikut: (1) manusia bertindak berdasarkan makna-makna sesuatu yang ada pada diri mereka; (2) makna-makna terhadap simbol itu merupakan hasil dari interaksi sosial dalam masyarakat; (3) maknamakna dimodifikasi dan ditransformasi melalui proses penafsiran yang dipergunakan oleh setiap individu dalam menghadapi simbol- simbol. ${ }^{6}$

Dalam menemukan faktor-faktor yeng membentuk pemahaman ikhwan mantan preman, peneliti menggunakan teori belajar sosial dan psikologi dakwah tiga tahap pembentukan mental seorang muslim Dr Mustafa Masyur. Dia berpendapat bahwa proses pembentukan kepribadian seorang muslim melalui tiga tahapan. Tahap penerangan (ta'rif) atau tahap propanda, memperkenalkan, menggambarkan ide (fikrah) dan menyampaikannya kepada khalayak ramai dan setiap lapisan masyarakat.)Tahap Pembinaan dan Pembentukan (takwin), yaitu tahapan pembentukan, memilih pendukung, menyiapkan pasukan, mujahid, dan mujahid dakwah serta menArifnya. dan tahap Pelaksanaan (Tanfidz), yaitu tahap beramal, berusaha, dan bergerak mencapai tujuan. ${ }^{7}$

\footnotetext{
${ }^{5}$ H.B. Sutopo, 2006. Metodologi Penelitian Kualitatif: Dasar Teori daan Terapannya dalam Penelitian. Solo: UNS Press 2015, hal 112

${ }^{6}$ M. Djamal, Paradigma Penelitian Kualitatif, Yogyakarta: Pustaka Pelajar,

${ }^{7}$ Musthafa Masyur. Fiqih Dakwah. Al-I'tishom Cahaya Umat. Jakarta. 2001, Jilid 1. Cet-2 hal 13-14
} 


\section{B. Pembahasan}

\section{Proses Pembentukan Idensitas}

Teori Belajar Sosial menyatakan bahwa lingkungan mempengaruhi sikap dan karakter seseorang. Seseorang yang hidup dalam lingkungan beradab dan berilmu maka ia akan tumbuh dalam adab dan keilmuan. Sebaliknya, anak yang hidup dan tumbuh dalam lingkungan yang tidak beradab maka ia akan bersikap tidak beradab. Hadist yang selaras dengan teori ini adalah hadist yang menyatakan bahwa setiap anak lahir dalam keadaan kesucian tetapi bapak ibunya (mewakili tetangga dan lingkungan masyarakat) yang menjadikan seseorang menjadi Yahudi, Nasrani, atau Majusi. Hal ini sebagaimana diriwayatkan oleh Imam Muslim dan Bukhari dari Abu Hurairah

"Tidaklah setiap bayi yang dilabirkan melainkan dalam keadaan suci, bapak dan ibu mereka yang menjadikan mereka beragama Yabudi, Nasrani atau menjadikan mereka melakukan kemusrikan" (HR. Bukrori dan Muslim)

Para preman merasakan bahwa proses perubahan menjadi preman terjadi pada masa remaja. Hal ini karena masa remaja adalah masa menunjukkan karakteristik perkembangan nilai, moral dan sikap. Perkembangan ini adalah proses bagi setiap remaja mencari identitas diri. Dalam menumbuhkan kepribadian dan sikap yang matang, para remaja melakukan identifikasi dan imitasi tokoh-tokoh model yang mereka lihat. Untuk itu, kondisi masyarakat yang menokohkan para preman dalam kehidupan sehari-hari menjadikan para remaja di Kampong Mojo ini menjadi nakal dan preman. ${ }^{?}$

Elly M. Setiadi dan Usman Kolip menyatakan bahwa interaksi secara tidak langsung membentuk kepribadian. Proses ini terjadi dimana individu yang tersosialisasi menyaksikan melalui indranya proses sosial berupa berbagai tingkah laku orang-orang yang berada disekitarnya. Pola-pola interaksi yang disaksikan

${ }^{8}$ (http://www.simplypsychology.org/bandura.html 2 Oktober 2016)

${ }^{9}$ Saring Marsudi, dkk.Layanan Bimbingan Konseling di Sekolah. Surakarta: Muhammadiyah University Press.2003, Hal 13 
tersebut selanjutnya di internalisasikan ke dalam mentalnya sehingga membentuk tingkah laku seseorang. ${ }^{10}$

Di daerah seperti ini, Ustad Andi melakukan pendekatan dakwah ala jamaah Tablig, tidak menyalah-nyalahkan, berkata santun, dan mengajak kebaikan. Secara kuantitas, umat Islam sebagai mayoritas, tetapi secara realitas, muslim yang mengamalkan Islam sangat minoritas. Sehingga, pola dakwah yang santun merupakan pola yang sangat tepat. Perbedaan menonjol dengan system dakwah beliau dengan Jama'ah Tablig secara umum adalah system pembinaan. Ust Andi tidak hanya mengajak tetapi juga membina, mengajarkan ilmu yang berdasarkan Al-Qur'an dan hadist serta penjelasan ulama yang lurus. Beliau menghindari ceritacerita yang tidak jelas asal sumbernya, beliau juga menghindari cerita-cerita isroiliyat (cerita-cerita dari orang-orang Yahudi). ${ }^{11}$

Pada masa awal dakwah, sebagian peserta pengajian datang dalam keadaan mabuk, sebagian mereka mengatakan perkataan yang melecehkan Ust Andi, tetapi beliau membiarkannya. Bagi beliau, kehadiran mereka di majlis ta'lim merupakan anugerah yang disyukuri. Perbedaan ustad Andi dengan ustad-ustad yang lain yang telah berdakwah di daerah ini adalah ajakan kepada yang belum sadar. Jika ustad-ustad yang lain hanya mengisi khutbah dan ceramah pada orang-orang yang pergi ke masjid, ust Andi mengajak dan mendakwahi orang-orang yang sudah sadar dan para pelaku maksiat. Setelah beliau berhasil mengajak dan mengajari mantan preman mengaji, beliau meminta mereka untuk mengajak teman-temannya yang belum sadar, baik secara lisan maupun secara undangan tertulis. System dakwah ini berjalan lancar dan berhasil mengubah Mojo menjadi lebih baik. (Wawancara dengan Pak Salman (Komandan Laskar mantan preman saat wawancara) 22 Oktober 2016)

${ }^{10}$ Elly M. Setiadi dan Usman Kolip, Pengantar Sosiologi, Jakarta; Prenadamedia Group, 2011, hal 174

${ }^{11}$ Hasil wawncara Ust Andi, 15 Oktober 2016 


\section{Faktor-faktor yang Mempengaruhi Preman Bertaubat}

Pertama adalah faktor umur yang menginjak masa berkeluarga. Renungan dan percakapan dalam batin mereka tentang apa yang akan terjadi pada diri mereka dalam beberapa tahun kedepan jika mereka tetap meneruskan kegiatan premanisme. Selain itu, tumbuhnya keinginan memiliki istri yang sholihah untuk membina keluarga yang baik. ${ }^{12}$ Proses taubat lain adalah tidak ditemukannya persaudaran atau pertemanan yang hakiki. Rasa penghormatan dalam dunia preman didasarkan perasaan ketakutan atau kelebihan harta yang bisa dimanfaatkan. Ketika kehidupan ekonomi membaik dan harta melimpah, Pak Amar menghamburkan uang untuk mentraktir teman-temannya membeli minuman keras dan mereka mabuk-mabuk an. Teman-temannya memanggilnya bos. Kehadirannya ditunggu, ketidak datangannya ditanyakan, dia dipuji dan disanjung-sanjung supaya uangnya keluar. Ketika terjadi kebangkrutan di tempatnya bekerja, Pak Amar menyadari bahwa dia dihormati karena uang yang dia miliki. Ketika itu, dia merasa hakekat persahabatan dalam dunia hitam tidak ada. Kehadirannya tidak dinantikan, keberadaannya menjadi bahan cemoohan teman-temannya yang dulu memanggilnya bos. Sejak saat itu, ia bertaubat dan belajar Islam. ${ }^{13}$

Pola sadar yang ketiga adalah ketakutan akan kematian. Pengalaman ini terjadi pada bapak Agung. Ia merupakan salah satu preman yang sudah melakukan berbagai macam kejahatan. Kegiatan mencuri atau merampok merupakan bagian dari kehidupannya. Uang hasil pencurian itu kemudian digunakan untuk berfoyafoya sampai habis, setelah itu melakukan aksi kejahatan lagi. Pola kehidupan ini berulang-ulang. Sampai pada suatu malam, dia dan teman-temannya mabuk-mabuk an sampai tidak sadar diri. Gempa parah Jogya dimana getarannya sampai di Solo membangun pak Agung dari tidurnya. Dia lari ke arah tanah lapang, mengarahkan

2016

${ }^{12}$ Hasil wawancara dengan Pak Arif (ikhwan mantan preman) 4 November November 2016

13 Hasil wawancara dengan Pak Amar (ikhwan mantan preman) 6 
pandangan ke langit kemudian hatinya tersentuh dan ia berkata dalam hati, apa yang akan terjadi padanya jika hari itu meninggal. Sejak kejadian itu, ia mulai sadar dan berusaha memperbaiki diri. ${ }^{14}$

Kejenuhan dengan kemaksiatan adalah pola taubat yang ke-empat. Pola kejenuhan ini terjadi pada preman yang sangat parah. Mereka merasa bahwa apa yang mereka lakukan sudah lebih rendah dari apa yang dilakukan hewan. Mereka sudah mencoba berbagai macam bentuk kemaksiatan dan pasti berujung kepada kegelisahan. Kemaksiatan baru selalu bermuara pada kebosanan dan kegelisahan. Pada saat-saat seperti itu, mereka merasa membutuhkan suasana yang berbeda dari pada yang biasa dilakukan. Mereka kemudian mencoba sesuatu yang bertolak belakang dari yang biasa mereka lakukan, yaitu kehidupan beragama. Sejak saat itu mereka bertaubat. ${ }^{15}$

Proses hidayah tidak mengenal istilah logis atau tidak logis. Bergelut dalam dunia preman sejak kecil sampai memiliki dua anak laki-laki, timbul keinginannya mengakhiri semua bentuk kegiatan preman jika memiliki anak perempuan. Laki-laki dengan mayoritas badan bertato dan bekerja sebagai orang yang menato para preman ini, kemudian meneguhkan niatnya ketika istrinya hamil anak ketiga dan lahir seorang perempuan. Dimasa awal taubat, sebagaimana para preman yang lain di awal masa taubat, ia mengaji dengan ustad Andi, tetapi kemudian kembali lagi melakukan kemaksiatan dan kemudian taubat lagi dengan masuk tim Hisbah, laskar nahi mungkar yang dipimpin ustad Sigit Qardawi. ${ }^{16}$

\section{Pengamalan Ajaran Islam di Awal Masa Taubat.}

Pengamalan ajaran Islam pada masa awal perubahan ikhwan mantan preman sangat unik. Mereka tidak bisa melepas masa lau meskipun mereka juga tetap mengaji. Menurut bapak

\footnotetext{
November 2016

${ }^{4}$ Hasil wawancara dengan Pak Agung (ikhwan mantan preman) 5 Oktober 2016

${ }^{5}$ Hasil wawancara dengan Pak Anton (ikhwan mantan preman 22

${ }^{16}$ Hasil wawancara dengan Pak Budi Tato (ikhwan mantan preman) 2 November 2016
} 
Salmani, pada siang di bulan Romadhon, dia pernah diajak mabukmabuk an oleh temannya, tetapi dia menolak karena dia sedang puasa, tetapi dia menjanjikan untuk melakukannya setelah sholat terawih. Di malam harinya, sesuai dengan janji yang dibuat, dia dan teman-temannya pesta miras setelah siang puasa dan malam sholat terawih. ${ }^{17}$ Keadaan yang sama juga dialami para ikhwan mantan preman. Di awal masa taubat mereka, mereka masih berbaur dengan teman-teman mereka di masa jahiliyah. Tetapi seiring bertambahnya ilmu dan meningkatnya keimanan, mereka akhirnya mampu meninggalkan kemaksiatan secara menyeluruh. Pertama-tama, mereka memantapkan diri menjauhi teman-teman yang mengajak mereka berbuat kemaksiatan. Yang kedua, mencari komunitas baru yang selaras dengan keyakinan mereka yang baru. Ketiga adalah menahan diri dari dorongan pribadi. Terakhir adalah dengan menambah ilmu dan amal dalam Islam.

Selain itu, masa lalu mereka yang bicara tanpa control, berdampak positif pada awal Islam ini. Mereka tidak malu untuk menanyakan sesuatu dimana orang secara umum malu melakukannya. Mereka juga secara sadar menceritakan masa lalu yang kotor dan bagaimana memperbaikinya. Berikut pernyataan ust Fajar menceritakan tentang kepolosan ikhwan mantan preman yang mengakui kesalahannya tanpa malu. Ketika pengajian, sebagian peserta ada yang bertanya dengan polos, "Ust, dulu aku pernah melempar kepala temanku itu dengan batu sehingga berdarah, apa yang harus aku lakukan?” ust Andi langsung menjawab "kamu minta maaf kepadanya!". Mendengar jawaban itu, orang yang bertanya langsung menuju orang yang pernah disakiti untuk meminta maaf dan ketika itu juga, mereka berdua saling memaafkan dan menjadi teman yang sangat baik.

Pada masa awal perubahan ini, para ikhwan mantan preman tidak melakukan tindakan apa-apa kecuali mengajak pelaku kemaksiatan untuk mengaji. Mereka tidak melarang orang yang berbuat maksiat selama mereka tidak menganggu orang Islam.

\footnotetext{
${ }^{17}$ Wawancara dengan Salman
} 
Pada masa ini, kemaksiatan di daerah Semanggi masih terhilat jelas, para ikhwan tidak melakukan tindakan kekerasan yang menakutkan preman. Sikap mereka kepada ust juga baik. Mereka menghormati ustad yang mengajari mereka nilai-nilai agama meskipun mereka tidak kenal sebelumnya. Belum nampak gesekan pemahaman dalam diri para ikhwan mantan preman.

Para ikhwan memiliki rasa berkorban dan simpatik kepada sesama muslim dan agama Islam tinggi. Mereka dengan ringan tangan mengeluarkan harta dan tenaga untuk pengajian atau kegiatan-kegiatan keislaman yang lain, seperti membantu pembangun masjid, pondok, atau perbaikan rumah-rumah teman mereka. Ketika mendengar salah seorang teman sakit dan dirawat di rumah sakit, mereka dengan segera berkoordinasi dengan teman-teman yang lain untuk mengumpulkan uang dan merencanakan menjenguk teman mereka itu. Contoh solidaritas yang lain adalah, ketika mendengar teman membangun rumah dan butuh tenaga untuk mengecor atap, mereka dengan terkoordinir datang membantu meskipun meninggalkan pekerjaan mereka. ${ }^{18}$

\section{Faktor-faktor yang mempengaruhi sikap ikhwan mantan preman dandampak pemikiran mereka di masyarakat pada masa awal perubahan.}

a. Faktor kehidupan masa lalu mendominasi tatacara ikhwan mantan preman mengamalkan Islam dan bersikap. Kehidupan preman yang tidak memiliki malu menjadikan mereka berani menanyakan sesuatu yang dianggap tabu kebanyakan orang. Selain itu, mereka juga berani menampakkan keislaman mereka melibihi orang yang sudah lama mengaji. Sebagai contoh, memakai kupiah di pasar, ketika sedang parkir, atau di tempat umum lainnya. Proses perubahan menjadi muslim yang sadar ini juga mereka bangun dalam keluarga mereka. Anak dan istri mereka cenderung menaati suami atau

\footnotetext{
${ }^{18}$ Hasil observasi kehidupan ikhwan mantan preman pada bulan Oktober sampai Desember 2016
} 
bapak mereka. Secara dhohir, suasana keislaman keluarga nampak dalam pakaian dan atribut keislaman lain.

b. Guru atau ustad yang menArif mereka adalah faktor kedua dalam dinamika perubahan pemikiran ikhwan mantan preman. Pada masa awal perubahan ini, penulis mendapat informasi tentang materi dan cara pendekatan yang diberikan ust Andi. Pendekatan hati ke hati dan pensucian hati sebagaimana yang diterapkan Nabi Muhammad kepada para sahabat di Makkah menjadi materi utama dalam dakwah beliau. Pola ini berdampak pada rasa welcome para preman terhadap dakwah.

\section{Keislaman Ihkwan mantan Preman di Masa Kelaskaran. (Pengamalan, Pengaruh dan dampak pemikiran mereka)}

Setelah keislaman ikhwan mantan preman membaik, ibadah mereka teratur dan kemaksiatan mereka tinggalkan, keinginan memperdalam keilmuan mereka bertambah. Mereka mulai mengaji ke beberapa ustad yang lain. Pada masa ini, mereka mengenal pola baroki (pergerakan) yang berbeda dengan ajaran ustad Andi dalam menanggapi kemaksiatan dan pemerintahan. Dengan semangat, para ikhwan mantan preman mulai belajar tentang wala' dan baro' serta meninggalkan pola pengajian ustad Andi. Menurut beberapa ikhwan, sebagai seorang muslim harus jelas dan tegas dalam bersikap. Mereka juga menyatakan akan kesesuaian hati mereka dengan pembahasan yang keras menurut sebagian orang itu.

Pada periode kedua keislaman ikhwan mantan preman, selain mereka bertemu para asatid yang tergabung dalam harokah, mereka juga bergabung dengan laskar. Pada kondisi ini, nalar preman mereka muncul. Jika di Jogja para preman mengubah identitas mereka dengan membuat suatu kelompok paguyupan Kawula Alit, tetapi tatacara preman yang mengandalkan kekuatan dan kekerasan mewarnai bungkus yang baru. ${ }^{19} \mathrm{Hal}$ ini juga terjadi

${ }^{19}$ Wasisto Raharjo Jati, Kuasa Dan Kekerasan : Kelembagaan PremanismeYogyakarta Paska Reformasi,Jurnal Sosiologi Islam, Vol. 2, No.1, April 2012, ISSN: 2089-0192 
pada lascar di Solo. Mereka lebih suka dengan konfrontasi fisik dengan para preman dari pada dakwah ala jamaah tablig, yang membujuk dengan kata-kata baik dan sabar ketika dimarahi. Mereka lebih suka melihat para preman mengakui superioritas mereka kemudian meninggalkan kemaksiatan. Nalar preman yang menggunakan pendekatan kekerasan dan kekuatan menjadi magnet bergabungnya mantan preman dari berbagai daerah.

\section{Pengamalan Ajaran Islam pada Periode ini}

Pada periode ini, para ikhwan telah mampu meninggalkan kemaksiatan berdosa besar atau aib masyarakat, seperti mabukmabukan, berzina, berjudi, memakai narkoba, dan mencuri. Mereka menyadari akan kesalahan perbuatan-perbuatan mereka di masa jahiliyah. Tidak hanya meninggalkan kemaksiatan-kemaksiatan tersebut, tetapi juga melawan tindakan-tindakan tersebut. Dalam hal tholabul ilmi, para ikhwan mantan preman rata-rata mensukai para ustad yang menyerukan jihad dan berjuang dengan aksi fisik. Mereka juga mulai membedakan ustad-ustad karena materi kajian. Mereka mengidolakan ustad yang berani menyampaikan materi tentang membasmi kemaksiatan dengan kekuatan. Sudut pandang mereka sudah berubah 180 derajat. Pada tahap ini, sebagian ikhwan mantan preman mulai meremehkan para ustad yang menyampaikan materi-materi tentang fikih, tarikh dan adab. ${ }^{20}$

Pada pola pembinaan secara haroki, penanaman kecintaan kepada Islam sebagai agama yang kafah, kewajiban mendirikan Negara Islam, memusuhi orang yang tidak mau berhukum kepada Al-Qur'an dan As Sunnah, kekufuran sistem demokrasi dan orang-orang yang mendukungnya, telah menimbulkan sikap ekstrim pada sebagian ikhwan mantan preman. Sebagian mereka menyukai para asatid yang mengkafirkan pemerintahan dan tidak menyukai bahkan membenci para asatid yang mau berbaur dengan orang-orang yang bekerja di pemerintahan.Semangat mereka semakin meningkat, ketika pemahaman itu bertemu dengan aksi

\footnotetext{
${ }^{20}$ Hasil wawancara Ust Umar (Mantan Pemimpin Laskar yang pernah dipenjara Nusakambangan) 12 November 2016
} 
nahi mungkar ustad Sigit Qardowi. Ustad Sigit Qardawi membina gerakannya dengan pengajaran teori kemudian praktek. Secara rutin, para ikhwan mantan preman berkumpul setiap malam Ahad. Ustad Sigit memberi tausiyah tentang kemuliaan Islam dan kewajiban meninggikan kalimat Allah. Setelah itu, mereka kemudian bergerak ke masyarakat dan lingkungan-lingkungan kemaksiatan untuk melaksanakan nabi mungkar. ${ }^{21}$

Akibat dari pemahaman mereka yang salah, sebagian mereka mengkafirkan pegawai negeri, lurah, apalagi polisi. Tidak hanya pegawai pemerintahan, mereka bahkan mengkafirkan orangorang yang mengikuti pemilihan umum. Tatacara pengambilan kesimpulan yang sederhana, demokrasi hukumnya haram dan merupakan system kafir, maka orang yang mengikuti kekufuran berarti kafir. Pemahaman ini berdampak pada pola pengamalan ajaran Islam, mereka tidak mau bermakmum pada imam yang mengikuti pemilu apalagi mendengar khutbah atau ceramah. Mereka mengisolalisasikan diri sendiri dengan pemahaman atau perasaan mereka.

Sementara sebagian besar ikhwan mantan preman tidak mengikuti pemahaman yang ekstrim, mereka tidak membenci perangkat kerja di pemerintahan kecuali polisi. Secara individu, mereka bisa menerima anggota polisi, tetapi mereka membenci polisi secara kelembagaan. Kebencian mereka kepada lembaga ini karena mereka menilai ada oknum polisi yang melindungi tempattempat kemaksiatan. Kebencian mereka semakin bertambah ketika polisi menghalangi langkah mereka untuk berbuat aksi, sementara mereka membiarkan kemaksiatan yang jelas-jelas melanggar hukum. Menurut pengakuan para laskar, tidak sekali atau dua kali, mereka diserang polisi ketika hendak melakukan nahi mungkar. ${ }^{22}$

Para ikhwan mantan preman yang berhaluan moderat, mereka sangat menghargai keberagaman. Mereka bisa berbincangbincang dengan orang yang aktif dari berbagai ormas Islam.

\footnotetext{
${ }^{21}$ Hasil Wawancara ke-2 dengan Pak Salman 2 Desember 2016

22 Pendapat mayoritas ikhwan mantan preman yang penulis wawancarai
} 
Mereka juga tidak mempermasalahkan bermakmum pada imam selain anggota laskar. Rasa hormat mereka kepada para asatid yang mengajari ilmu-ilmu syar'i seperti fikih maupun sirah baik, meskipun secara umum mereka juga menyukai materi-materi yang bersifat konfrontasi dengan pemerintahan dan kemaksiatan.

\section{Tiga Pilihan yang ditawarkan Laskar Kepada Preman Ketika Beraksi}

Dalam melakukan aksi melawan semua kemaksiatan di masyarakat dan jalanan. Para ikhwan laskar selalu memberikan tiga pilihan kepada pelaku kemaksiatan.Pertama, dilaporkan kepada Polisi. Dari pengalaman para ikhwan laskar, belum ada yang mengambil pilihan ini. Bagi preman, ini pilihan yang paling sulit, selain ancaman penjara yang akan menghilangkan ruang gerak mereka, dana yang besar juga dibutuhkan untuk berhadapan dengan polisi. Pilihan kedua adalah bertaubat. Para ikhwan menuntut para preman yang memilih pilihan ini untuk menjaga sholat wajib secara berjamaah di masjid sebagai bentuk nyata taubat mereka. Banyak preman yang memilih pilihan ini, tidak hanya bertaubat, sebagian besar mereka juga bergabung dalam aksi nahi mungkar. Untuk itulah, jumlah laskar bertambah banyak hari demi hari, meskipun tidak semua preman secara pemahaman dan ketulusan bergabung dengan laskar. ${ }^{23}$

Menurut salah satu komandan laskar, ada tiga alasan para preman bergabung dengan laskar. Pertama, mereka bergabung dengan laskar karena mereka takut dengan laskar. Salah satu preman yang bergabung dengan laskar karena takut bernama Jetir. Dia secara aktif sholat ke masjid dan bergabung dengan kegiatan pengajian para laskar. Tetapi, suatu hari, dia melarikan salah satu motor jamaah masjid sehingga pimpinan laskar memanggil dan menghukumnya. Setelah beberapa saat mengakui kesalahannya, dia tetap aktif ke masjid. Tetapi setelah beberapa bulan, tersiar berita bahwa pelaku di tangkap polisi karena kasus pemakaian Narkoba.

${ }^{23}$ Hasil wawancara Salman dengan komandan laskar 
Alasan kedua preman bergabung dengan laskar adalah hilangnya pengaruh di duniapreman. Hal ini menjadikannya tidak bisa meminta uang keamanaan kepada pemilik warung atau pengusaha di daerahnya. Preman ini menginginkan keberadaan dia sebagai orang yang ditakuti di kampungnya kembali, untuk itu, mereka bergabung dengan laskar. Alasan ketiga adalah hidayah dari Allah SWT. Sebagaimana telah penulis bahas pada bab sebelumnya. Beberapa preman dengan kesadaran diri merasa bosan dengan kehidupan preman dan memilih kehidupan secara islami.

Pilihan ketiga kepada preman adalah berperang dengan laskar. Di daerah dengan tingkat kriminalitas tinggi, para preman memprofokasi masyarakat untuk menyatakan perang dengan laskar. Beberapa peristiwa bentrok antara laskar dan preman yang dibantu warga terjadi dibeberapa daerah, salah satunya adalah bentrok antara mereka di Losari kelurahan Semanggi. Dukuh ini berdampingan dengan daerah Mojo tempat para laskar dan dipisah oleh tanggul. Peristiwa bentrok terjadi pada tahun 2008, ketika preman merasa diganggu kebebasan mereka dengan datangnya laskar. Penduduk dukuh Losari yang secara umum pelaku maksiat sepakat untuk melawan laskar. Terjadi bentrok fisik antara dua kampong bersebelahan ini. Dengan usaha terus menerus oleh para laskar, para preman akhirnya menyerah dan daerah Losari akhirnya bersih dari Miras dan membaik.

\section{Faktor-faktor yang mempengaruhi pemikiran ikhwan mantan preman}

Faktor-faktor yang mempengaruhi pemikiran ikhwan mantan preman pada periode ini antara lain.

Faktor yang pertama adalah faktor ustad atau pembimbing mereka. Pada tahap ini, ustad yang mengisi pemikiran mereka berlatar belakang gerakan. Sehingga pola mereka berbeda dengan ustad Andi yang memiliki pendekatan pensucian atau pembersihan jiwa pola jamaah tablig.Faktor yang kedua adalah masa lalu mereka 
yang suka konfrontasi atau kekerasan dalam menyelesaikan masalah. Pada masa menjadi preman, mereka terbiasa tawuran, mengroyok, dan menyakiti orang untuk tujuan mereka. Faktor yang ketiga adalah kondisi medan nabi mungkar. Kondisi tidak normal dalam melakukan kegiatan nahi mungkar mempengaruhi sikap dan pemikiran mereka. Dengan jumlah yang lebih banyak, preman pelaku kemaksiatan sering melakukan perlawanan terhadap himbaun laskar. Menurut komandan laskar, hal pertama yang dilakukan para ikhwan mantan preman yang terjalin dalam tim Hisbah adalah menasehati pelaku kemaksiatan, ketika terjadi perlawanan maka mereka berkelahi. ${ }^{24}$

\section{Dampak Pemahaman dan Pengamalan Keislaman Pada Periode Kedua}

Pertama, Sikap tegas mereka terhadap pelaku mabukmabuk an, pencurian dan kemaksiatan yang lain. Mereka memiliki mata-mata yang disebarkan di daerah-daerah sekitar semanggi dan daerah lain. Pola gerak seperti ini tergolong efektif. Tidak dalam hitungan tahun, Semanggi pada khususnya telah bersih dari miras. Kedua, Pemahaman terhadap wala' dan bara' mengarah kepada sesuatu A'sobiyah terhadap pemahaman ustad. Wala' diberikan kepada seseorang yang sesuai dengan mereka dan baro' diarahkan kepada orang yang tidak sesuai dengan pendapat mereka. Ketiga, Pada periode ini, tradisi Tabayun atau klarifikasi kebenaran berita luntur di kalangan ikhwan mantan preman. Berita tentang kesalahan seorang ikhwan atau ustad bisa menyebar sangat cepat tanpa ada tabayun. Hal ini berdampak pada retaknya jamaah ikhwan mantan preman ini. Mereka bisa membenci seseorang karena berita miring yang tersebar pada kalangan mereka tanpa ada klarifikasi. (Hasil Observasi antara September - Desember 2010)

\footnotetext{
${ }^{24}$ Hasil observasi kehidupan ikhwan mantan preman pada bulan Oktober sampai Desember 2016
} 


\section{Pola Perekrutan Anggota Tim Hisbah}

Sebagai Tim Nahi Mungkar baru, pertumbuhan jumlah anggota Tim ini relative cepat. Tim ini terdiri dari berbagai gabungan kelompok-kelompok pemuda remaja masjid di Solo. Ust Sigit telah memiliki ratusan anggota laskar Bismillah, Ust Umar pernah meminpin empat ratusan anggota laskar Permaja ketika memimpin pembubaran rumah penduduk yang digunakan Vigara di Joyotakan. Jumlah pertama gabungan antara dua komandan gede dan komandan cilik ini sudah mencapai lima ratusan. Konsistensi gerakan Tim Hisbah dalam menjalankan nabi mungkar ini menjadi magnet bagi para remaja masjid dan para ikhwan mantan preman untuk bergabung sebagai wujud keinginan beramal dalam perubahan dan menyalurkan keinginan untuk merubah kerusakan yang tidak bisa dilakukan ketika sendirian atau tidak diakomodir oleh ormas tempat mereka bergabung. ${ }^{25}$

Ust Sigit dan komandan yang lain selalu mengadakan kajian tentang kemuliaan Islam dan pentingnya menghapus kemaksiatan, kemudian mereka langsung memimpin pasukannya berhadapan dengan preman. Metode ini telah berhasil mengumpulkan para pemuda dan membangkitkan semangat mereka. Benyak pemuda dari berbagai elemen umat Islam di Solo bergabung dalam Tim Hisbah. Mereka berasal dari Majelis Tafsir Al-Qur'an, pemuda Muhammadiyah, Hisbullah, Jundullah, FKAM, MMI atau para pemuda remaja masjid umum yang belum tergabung dalam ormas manapun.

Cara kedua adalah dengan penaklukan para preman di daerah tertentu kemudian membimbing mereka dalam Halaqoh. Setiap daerah yang pernah mereka taklukan, para anggota preman disarankan untuk sadar dan bergabung dengan mengikuti kajian mereka jika tidak ingin berkonfrontasi dengan laskar. Dengan pola seperti ini, daerah yang terkenal akan kerusakannya seperti Mojo, Losari, Sangkrah, Sumodilagan, Made Gondo, Mojo Laban, Mojo

\footnotetext{
${ }^{25}$ Wawancara dengan Umar....
} 
Songo dan daerah lain, menjadi kantong-kantong pengajian dan anggota laskar.

Perubahan sikap ust Sigit terjadi ketika Ust Abu Bakar Ba'asir kembali ditangkap polisi dengan tuduhan memerintahkan latihan militer di Aceh. Darah ust Sigit dan pemuda yang lain membara melihat kedzoliman ini, tetapi mereka tidak memiliki kekuatan yang cukup untuk membalas polisi. Dalam masa kemarahan ini, dia dan tim hisbah mengundang dan mendapat tausiyah Ustad Aman Abdurrohman yang terkenal keras akan pentingnya melakukan perlawanan. Pertemuan dengan Aman Abdurrohman menjadikan Sigit dan teman-temannya bersemangat melakukan aksi jihad. Terjadi perubahan yang sangat drastis pada pemikiran ust Sigit dan komandan-komandan Hisbah. Tim Hisbah menjadi kelompok yang sangat eksklusif, jika dulu mereka menerima berbagai elemen ormas Islam untuk bergabung dengan tujuan yang sama, pada periode ini, mereka menerapkan bai'at kepada anggota. ${ }^{26}$

Pada periode ini, mereka juga menghalalkan merampas harta orang kafir atau yang dianggap kafir. Kegiatan Nahi Mungkar mulai berkurang, mereka lebih menyukai aktivitas untuk menyonsong jihad. Penggalangan dana terus dilakukan dengan berbagai cara, mereka menghalalkan harta orang yang kafir untuk membeli senjata. Kegiatan ini kemudian tercium oleh DenSus sehingga ust Sigit menjadi buronan. Rasa tanggung jawab kepada anggota yang membuat ust Sigit tidak mau meninggalkan Solo dan bersembunyi meskipun dia tahu kalau dia menjadi buronan. Untuk itu, dia berhasil diburu oleh Densus dan meninggal pada hari Sabtu 11 Mei 2011.

Semenjak meninggalnya ustad Sigit Qardawi yang ditembak densus 88, kondisi para anggota laskar seperti ayam kehilangan induknya. Secara umum, mereka terpecah menjadi dua kelompok pemikiran. Satu kelompok beraliran keras dan kelompok yang lain masih seperti tim Hisbah yang dibentuk pertama kali. Dalam perpecahan dua pemikiran ini, mereka berdiri dalam beberapa

${ }^{26}$ Wawancara dengan Umar.... 
komando, tetapi secara resmi kelembagaan, Tim Hisbah dipimpin oleh Ust Agus Junaedi sebagaimana wasiat dari pimpinan umum. Pada pembahasan terakhir ini, peneliti membahas hal-hal berikut;

\section{Pemahaman dan Pengamalan Ajaran Islam Ikhwan yang Ekstrim}

Para ikhwan mantan preman yang berhaluan keras, mereka masih berpedoman dengan ajaran Aman Abdurrohman dengan Aqidah Takfir Ta'yin, yaitu keyakinan akan kekufuran orang-orang yang berdosa besar dan berkonfrontasi dengan orang-orang yang bersebrangan dengan pemikiran mereka. Mereka mengkafirkan orang bekerja dalam instansi pemerintah. Mereka menggunakan kaidah umum "barang siapa tidak mau mengkafirkan orang kafir, maka dia juga kafir". Kaidah ini kemudian dibawa pada penafsiran surat Al Maidah ayat 44 yang artinya "barang siapa tidak mau berhukum dengan hukum Allah maka dia kafir". Karena pemerintah Indonesia tidak berhukum dengan hukum Allah, maka pemerintah dan semua orang yang bekerja di instansi pemerintahan juga kafir berdasar ayat di atas. Pemahaman ini seperti bola salju, mereka berpendapat, siapa yang tidak mau mengkafirkan orang yang dicap kafir oleh Al-Qur'an maka dia juga kafir.

Dalam melakukan aksi nahi mungkar, pada masa ini, mereka menganggap bahwa harta yang digunakan oleh pelaku maksiat yang mereka anggap musuh adalah harta Fa'i atau harta rampasan perang yang halal bagi mereka. Untuk itu, ketika mereka melakukan razia orang-orang yang berpacaran, mereka kadang membawa helm para pelakunya. Ketika mereka membubarkan perjudian, mereka kadang membawa uangnya, dan membawa HP pelaku kemaksiatan tersebut. Kebijakan penenggelaman uang hasil perjudian atau penitipan Hp kepada penduduk lokal tidak berlaku pada periode ini. Meskipun ini dilakukan oleh beberapa orang yang berjumlah sedikit, tetapi pencemaran nama laskar meluas pada mereka yang tetap lurus. ${ }^{27}$

\footnotetext{
${ }^{27}$ Wawancara dengan Umar ... .
} 
Selain aksi nahi mungkar, semangat jihad juga mengakar dalam jiwa mereka. Mereka sangat bersemangat untuk bisa melakukan aksi terror yang menargetkan polisi. Tanpa bimbingan para ulama atau asatid, pola pengamalan jihad ini menuruti keinginan bukan pemahaman akan keilmuan tentang jihad. Yang ditakutkan para ulama dan asatid adalah pemanfaatan semangat mereka yang sebenarnya asset besar umat Islam oleh orang-orang yang berkepentingan selain kepentingan Islam itu.

\section{Pemahaman dan Pengamalan Ajaran Islam Para Ikhwan yang Moderat}

Setelah kematian ust Sigit Qardawi, ikhwan mantan preman yang moderat mulai memiliki kesadaran untuk mencari ilmu. Jika pada periode kedua, mereka menyukai materi tentang jihad, wala' dan Baro' serta meremahkan ilmu-ilmu seperti fikih, tarikh, dan adab, pada periode ini, mereka mulai mendatangi majelis ta'lim untuk belajar ilmu-ilmu tersebut. Pola ini tidak terlepas dari inisiatif komandan laskar yang menyadari akan pentingnya ilmu dalam pembinaan mental dan akhlak.

Para ikhwan mantan preman yang berpikiran moderat ini tidak membatasi diri mereka pada ustad-ustad tertentu. Mereka menghormati ustad-ustad yang memiliki kredibilitas akan keilmuan dan pengamalan keislamannya. Mereka menyadari kapasitas diri mereka yang berangkat dari masa lalu kelam dan tidak paham Islam, sehingga mereka tidak mau menyalahkan orang yang berbeda pendapat apalagi menyalahkan para ustad. Mereka berbaur dengan masyarakat sebagaimana seorang muslim secara umum. Mereka sholat berjamaah dan bermakmum pada asatid dari berbagai ormas.

Secara umum, para ikhwan mantan preman mengkafirkan system demokrasi, tetapi mereka tidak menyalahkan atau mengkafirkan orang mengikuti pemilu. Sikap mereka kepada ustad 
yang menganjurkan supaya umat Islam memilih pimpinan muslim karena hanya terdapat dua calon wali kota, mereka tetap hormat dan bersikap baik. Dalam diri para ikhwan mantan preman ini, mereka berkeyakinan bahwa Indonesia adalah Negara berpenduduk mayoritas muslim tetapi memakai system kafir, mereka juga sangat mencita-citakan tegaknya hukum Islam di Negara ini. Sikap mereka kepada para pekerja pemerintahan baik kecuali kepada para polisi.

Selain dalam lingkungan ilmu, pola gerakan nahi mungkar pada periode ini lebih mendahulukan laporan masyarakat akan adanya praktek kemaksiatan di lingkungan mereka. Mereka lebih mengutamakan laporan dari masyarakat, kemudian para anggota bergerak dan mendatangi lokasi kemaksiatan, setelah itu, mereka mengundang RT maupun RW untuk menjadi penentu hukuman juga. Hal ini menimbulkan perasaan simpatik masyarakat kepada laskar dan cenderung mendukung kegiatan ini. ${ }^{28}$

Faktor terbesar dari perubahan pemikiran ikhwan mantan preman adalah meninggalnya pemimpin mereka ustad Sigit Qardawi yang ditembak densus 88 . Selain belum ada sosok pengganti beliau, umur laskar juga tergolong muda. System keorganisasian mereka belum terbentuk dengan baik, mereka masih mengandalkan ketokohan. Sehingga ketika tokoh mereka meninggal maka mereka tidak memiliki pegangan untuk menentukan arah. Faktor kedua adalah tertangkapnya beberapa anggota senior laskar. Mereka lebih berhati-hati dalam melakukan aksinya. Pola kerja mereka yang lebih berhati-hati mempengaruhi anggota yang lain. Kelebihan dari tindakan ini adalah adanya perencanaan yang matang dalam melakukan aksi, mereka selamat dari jerat hukum tetapi kemaksiatan tetap hilang. Ketiga,tumbuhnya kesadaran dari komandan laskar akan pentingnya ilmu dalam gerakan mereka. Kesadaran ini menginisiatif komandan dan para senior untuk mengumpulkan anggota dan mengundang ustad. Pola pemikiran laskar yang menghormati dan mentaati pemimpin menjadikan ta'lim para ikhwan berjalan.

\footnotetext{
${ }^{28}$ wawancara ke-2 dengan pak Salman ... .
} 
Sementara faktor utama yang mempengaruhi pemikiran ikhwan mantan preman yang berhaluan keras adalah ajaran ust Aman Abdurrohman. Dia menyebarkan pemikiran tentang pemahaman Takfir dan jihad global. Para pengikut paham ini mengkafirkan orang yang tidak mengkafirkan pemerintah, Anggota Dewan Perwakilan Rakyat DPR, orang yang bekerja di pemerintahan, pejabat pemerintahan dari pusat sampai RT, orang yang ikut pemilu, atau orang-orang yang difatwakan kafir oleh Aman Abdurrohman. Pikiran ini membentuk satu gerakan yang tidak mau membaur dengan gerakan yang lain.

\section{Simpulan}

Ikhwan mantan preman merupakan asset yang sangat berharga bagi umat Islam. Mereka merupakan garda terdepan dalam menjaga kemuliaan Islam. Keberadaan laskar umat Islam telah mengancam keberadaan laskar merah, dengan menghilangnya laskar umat Islam maka laskar merah akan muncul kembali. Dalam kehidupan nyata, ikhwan mantan preman menjaga keamanan yang nyata dari gangguan para preman yang selayaknya didukung. Keberadaan mereka memberikan efek nyata dengan menghilangnya kasus pelecehan terhadap jamaah masjid dan hilangnya kejahatan yang merugikan para pemilik modal atau masyarakat umum.

Dinamika pemikiran mereka merupakan sesuatu yang unik. Ilmu mereka yang sangat terbatas tetapi memiliki kecintaan kepada Islam melebihi orang-orang yang hidupnya jauh dari kemaksiatan. Perubahan pemikiran mereka berawal dari taubat dari masa kelam mereka. Kehidupan preman yang keras menjadikan mereka menjadi pribadi yang cenderung pada kekerasan. Pada awalnya, ustad Andi hanya memberikan materi tazkiyatun nufus yang membuat mereka menjadi pribadi yang santun kepada kemaksiatan. Mereka lebih mendahulukan ajakan kepada kebaikan dari pada pemaksaan untuk menghentikan kemaksiatan dengan kekuatan. Meskipun perubahannya relative lambat tetapi jumlah preman yang bertaubat bertambah sedikit demi sedikit. 
Seiring bertambahnya waktu, mereka mulai tertarik untuk belajar tidak hanya pada satu orang, mereka bertemu ustadustad yang mengikuti harokah. Materi mereka keras terhadap kemaksiatan dan pemerintah yang tidak islami. Jiwa mereka yang keras seperti ketemu dengan jodohnya. Materi-materi tentang militer dalam Negara Islam menjadi materi favorit mereka. Prinsip mereka, haram hukumnya diam ketika melihat kemaksiatan sementara mereka mampu mencegahnya dengan kekuatan. Jiwa mereka yang suka menyelesaikan masalah dengan kekuatan seperti ketika berada pada zaman jahiliyah membara. Keadaan kejiwaan mereka yang membara kemudian bertemu dengan seorang pemuda yang memiliki jiwa kepemimpinan dan tegas dalam kemaksiatan. Terbentuklah sebuah front kekuatan yang menghadapi setiap kekuatan preman. Tentara Allah ini ternyata memenangkan setiap gesekan dengan preman. Para preman kemudian bergabung dengan laskar atau menyembunyikan niat jahat mereka. Hal ini menjadikan kehidupan masyarakat Solo menjadi tentram dan aman. 


\section{DAFTAR PUSTAKA}

Ahmad Warson Munawir, Al-Munawir, Surabaya: Pustaka Progressif, 1997

M. Djamal, Paradigma Penelitian Kualitatif, Yogyakarta: Pustaka Pelajar, 2015

H.B. Sutopo, 2006. Metodologi Penelitian Kualitatif: Dasar Teori daan Terapannya dalam Penelitian. Solo: UNS Press

Musthafa Masyur. Fiqih Dakwah. Al-I'tishom Cahaya Umat. Jakarta. 2001, Jilid 1. Cet-2

Saring Marsudi, dkk.Layanan Bimbingan Konseling di Sekolah. Surakarta: Muhammadiyah University Press. 2003

Elly M. Setiadi dan Usman Kolip, Pengantar Sosiologi, Jakarta; Prenadamedia Group, 2011

wawancara pertama dengan Ust Agus Junaidi (korlap lascar ketika penyerangan), 10 Oktober 2016

Wawancara ke-dua dengan Ust Fajar As Shidiq (Ustad mantan preman), 11 November 2016

Wasisto Raharjo Jati, Kuasa Dan Kekerasan : Kelembagaan Premanisme Yogyakarta Paska Reformasi, Jurnal Sosiologi Islam, Vol. 2, No.1, April 2012, ISSN: 2089-0192

Hasil wawancara Ust Andi, 15 Oktober 2016

Hasil wawancara dengan Pak Arif (ikhwan mantan preman) 4 November 2016

Hasil wawancara dengan Pak Amar (ikhwan mantan preman) 6 November 2016

Hasil wawancara dengan Pak Agung (ikhwan mantan preman) 5 November 2016

Hasil wawancara dengan Pak Anton (ikhwan mantan preman 22 Oktober 2016

Hasil wawancara dengan Pak Budi Tato (ikhwan mantan preman)

2 November 2016 
Hasil wawancara dengan Pak Agus Juanidi (mantan komandan laskar) 10 Oktober

Hasil wawancara dengan Pak Salman (Komandan Laskar) 11 Oktober

Hasil wawancara Ust Umar (Mantan Pemimpin Laskar yang pernah dipenjara Nusakambangan) 12 November 2016

(http://kbbi.web.id/preman-2. Sabtu 13 Agustus 2016)

(http://www.simplypsychology.org/bandura.html 2 Oktober 2016)

Hasil observasi kehidupan ikhwan mantan preman pada bulan Oktober sampai Desember 2016 